\title{
The Negative Impact of Climate Change on Environment Balance and Species, Number of Fish on Tigris River in Mosul Dam/ Duhok, Kurdistan Region of Iraq
}

\author{
Shokri Omar Mustafa* \\ Department of Fish Resources, Iraq
}

Submission: February 11, 2017; Published: April 17, 2017

*Corresponding author: Shokri Omar Mustafa, Head of fish resources department, Agriculture Engineer, Consultant, Iraq, Email: shokri.mustafa@uqconnect.edu.au

\begin{abstract}
This research study is the only research that has been conducted on the Tigris River in Mosul Dam in Sumel District (Duhok Province, Kurdistan Region of Iraq). It needs more studies should be do in the future because the climate change has already impact on it. This appears a new species of fish called shikhat fish locally that impact negatively on balance of fish species, especially carp fish and shabout fish. It is selected the part of the Dam in the Tigris River that located (Duhok Province) because of the safety, fresh and clean water. This part considers the best part of fishing and raising fish with cage fish culture system because we set up many square and circle cage fish culture on that area. Also, all these reason help us to succeed our study in terms of environment, health and economic aspects. The main aspect is to know what causes to affect negatively on fish species balancing, especially carp and shabout fish in the Tigris River in Mosul Dam.

We did a fishermen survey and it divided fish survey into two groups of fishermen, one group includes (fishing carp and shabout fish) and the two groups include (fishing shikhat fish). Furthermore, the water is supply into Mosul Dam from Tigirs River from Turkey.

At the beginning, we thought that Shikhat fish comes from Turkey through Tigris River, but the result shows an opposite because the negative impact of the global warming has been increased the number of Shikhat Fish and that can tolerant bad circumstances such as low dissolved Oxygen, High Temperature, low nutrient value of water and others nutrients such as phytoplankton, zooplankton and other nutrients. It also shows increases the number of shikhat fish alarmingly since 2007 till now.
\end{abstract}

This indicates that the shikhat fish will spread very quickly in Mosul Dam in Tigris River and it can impact negatively on other species of fish that affecting on Fishermen income in Duhok Province in terms of decrease their income, which leads to socio-economic problem.

In our study there were significantly differences in terms of number between shikhat fish and carp fish and shabout fish, and it has an obvious explanation because of difference in species of fish. It may get curious result that needs further investigation. Perhaps this reflects species of fish, level and source of water, natural food variety such as Plankton to name but a few of the variables that could be investigated. It also led us to follow up the research, recording more data and continuing research in the future.

Keywords: Climate change; New fish species (Shikhat locally called); Natural food; Fishermen; Environment balance

\section{Introduction}

The climate change has been impacting negatively on fish diversity in Duhok province such as in Dams, Rivers, Lakes, and other sources of water. Resolving the effect of climate change on fish populations is complicated, because climate change affects a multitude of environmental factors that may affect various processes at different levels of biological organization [1] (Lehodey et al. 2006; Tasker 2008). For example, even if the effect of changes in an environmental factor on the physiology of an organism is known (Christopher et al. 2006). It will be difficult to evaluate the outcome of this organism-level physiological response at the population or ecosystem level (MacKenzie and Köster 2004). Statistical analysis of available time-series revealed changes in distribution and abundance of fish species that correlate with environmental variables (Perry et al., 2005; Weijerman et al., 2005; Heath, 2007). However, statistical correlations do not necessarily indicate underlying processes (Köster et al., 2005). 
It may be argued that it will be impossible to detect generalities in the response of fish populations to climate change, because the number of influential factors is excessively large and individual species may differ too widely in their response. Nevertheless, we believe that it is possible to derive common patterns by developing hypotheses about the effect of climatic factors (abiotic variables) on fish populations, based on first principles and by taking account of different levels of biological organization (from cellular- and organism-level eco-physiology to population and ecosystem-level responses. We review the environmental variables and oceanographic features relevant to fish that are most likely to be affected by climate change, derive theoretical expectations from first principles and physiological and ecological theory, derive working hypotheses for future research, and review the empirical evidence from a selection of well-studied species in the Northeast Atlantic ecosystems against such a theoretical background [2].

In addition, the negative effect of climate change on Mosul dam and other sources of water in Duhok, Kurdistan Region of Iraq causes and appears a new fish species called locally (Shikhat Fish) [3]. This research is the only research that has been done on Tigris River and Mosul dam. It needs more study should have be done on it because the climate change has already impact on it and it appear a new species of fish [4] (Christopher et al. 2006).

The Tigris (taigris) is the eastern member of the two great rivers that define Mesopotamia, the other being the Euphrates. The river flows south from the mountains of southeastern Turkey through Iraq and empties itself into the Persian Gulf [5].

The Tigris is $1,850 \mathrm{~km}$ long, rising in the Taurus Mountains of eastern Turkey about $25 \mathrm{~km}$ southeast of the city of Elazig and about $30 \mathrm{~km}$ from the headwaters of the Euphrates. The river then flows for $400 \mathrm{~km}$ through Turkish territory before becoming the border between Syria and Turkey. This stretch of $44 \mathrm{~km}$ is the only part of the river that is located in Syria [6].

Mosul Dam, in Kurdish: (Bêndava Mûsil), Chambarakat Dam, formerly known is the largest dam in Iraq. It is located on the Western of Duhok Governorate and in the western governorate of Ninawa, upstream of the city of Mosul. At full capacity, the hydroelectric dam holds about 11.1 cubic kilometers $(2.7 \mathrm{Cu} \mathrm{mi})$ of water and provides electricity to the 1.7 million residents of Duhok and Mosul. The dam's main 750 megawatts $(1,010,000 \mathrm{hp})$ power station contain four 187.5 megawatts $(251,400 \mathrm{hp})$ Francis turbine-generators.

A pumped-storage hydroelectricity power plant with a capacity of 250 megawatts $(340,000 \mathrm{hp})$ and a run-of-the-river dam downstream with a 62 -megawatt $(83,000 \mathrm{hp})$ capacity also belong to the Mosul Dam scheme. It is ranked as the fourth largest dam in the Middle East, measured by reserve capacity, capturing snowmelt from Turkey, some 70 miles $(110 \mathrm{~km})$ north. Built on a karst foundation, concerns over the dam's instability have led to major remediation and rehabilitation efforts since the 2003 invasion of Iraq [5,6]. It is selected the part of the Dam that located in Khank, Sumel District, Duhok province because of the safety and fresh and clean water. Furthermore, this part is consider the best part of raising fish with cage fish culture and fishery because we have a hundred fishermen and we also set up many circle cage fish culture on it. Also, we used Fish hatchery pond (Indoor), all these reason help us to succeed our study $[4,5]$.

It has been chosen (10 years) for this study (2007 to 2016) because the Common Carp and other species of Fish has been decrease disturbingly and new fish (Shikhat Fish) has been increasing alarmingly for the last ten years $[4,5]$. For all these reasons we decided to conduct this study at Mosul Dam (KhankSumeel- Duhok Governorate, Kurdistan Region of Iraq).

\section{Materials and Methods}

The study is conducted in (Sumeel District- Duhok province, Kurdistan Region of Iraq). It used many places that fishermen have been using for fishing and the Ministry of Agriculture and Water Resources- General Directorate of Agriculture- Fish Resources Department support them in terms of license and others.

They have been chosen certain groups of fishermen for the last ten years from 2007 to 2016 with using different kind of net in terms of size. The study should select three factors but it have chosen two factors because of Kurdistan Region Government economic crisis and ISIS war in terms of Water Biology and species of fish. It divided fishermen into two group, one group include (70 fishermen) using different size of net, and other group include (55 fishermen) with using different size as well. Furthermore, the water specification is also included.

\section{Results}

Table 1: It shows that the number of new species (shikhat fish) has been increasing alarmingly for (10) years since 2007 to 2016.

\begin{tabular}{|c|c|c|c|c|}
\hline \multirow[b]{2}{*}{$\#$} & \multirow[b]{2}{*}{ Year } & \multicolumn{2}{|c|}{ Species of Fish \% } & \multirow[b]{2}{*}{ Notes } \\
\hline & & $\begin{array}{l}\text { Common } \\
\text { carp and } \\
\text { Shaboot } \\
\text { fish }\end{array}$ & $\begin{array}{c}\text { New fish } \\
\text { (Shikhat } \\
\text { fish) }\end{array}$ & \\
\hline 1 & 2007 & $50 \%$ & $50 \%$ & \multirow{10}{*}{$\begin{array}{l}\text { The new fish species } \\
\text { (Shikhat fish) locally } \\
\text { called has been } \\
\text { increasing alarmingly } \\
\text { year after year }\end{array}$} \\
\hline 2 & 2008 & $45 \%$ & $55 \%$ & \\
\hline 3 & 2009 & $40 \%$ & $60 \%$ & \\
\hline 4 & 2010 & $35 \%$ & $65 \%$ & \\
\hline 5 & 2011 & $30 \%$ & $70 \%$ & \\
\hline 6 & 2012 & $25 \%$ & $75 \%$ & \\
\hline 7 & 2013 & $20 \%$ & $80 \%$ & \\
\hline 8 & 2014 & $15 \%$ & $85 \%$ & \\
\hline 9 & 2015 & $10 \%$ & $90 \%$ & \\
\hline 10 & 2016 & $5 \%$ & $95 \%$ & \\
\hline
\end{tabular}

Throughout the period (10 years), it indicated that (Table 1) the number of shikhat fish increased alarmingly and in the last 
year the amount of shikhat catching is reach between $(30-75 \mathrm{~kg} /$ fishermen), which means that the negative aspect has been already impacting on other species of fish in Mosul Dam such as common carb and shabout fish (Table 2) (Figure 1).

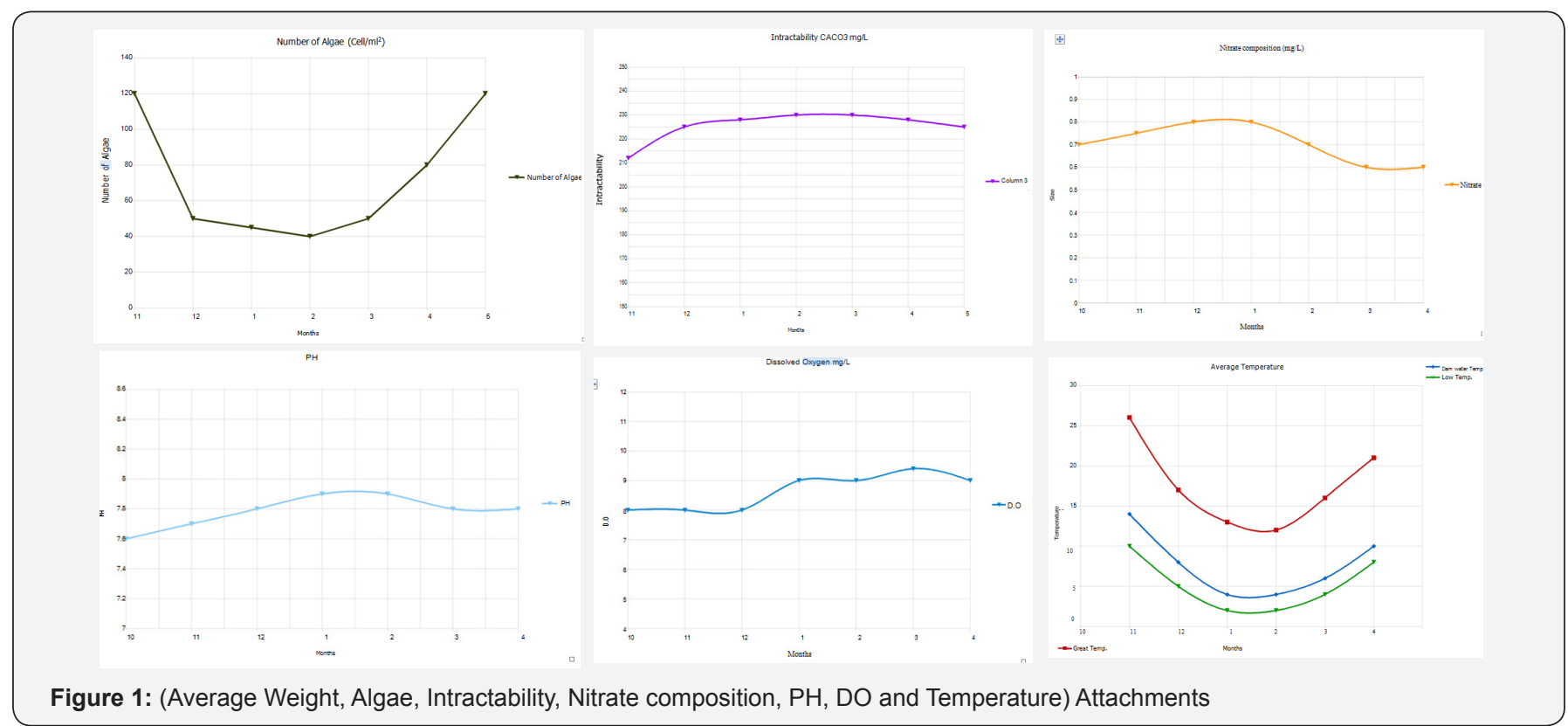

Table 2: Average weight $(\mathrm{g})$ of Shikhat Fish.

\begin{tabular}{|c|c|c|c|c|}
\hline$\#$ & Item & Group 1 & Group 2 & Notes \\
\hline 1 & $\begin{array}{c}\text { Weight (g) } \\
\text { in Winter }\end{array}$ & $150-385$ & $155-402$ & \\
\hline 2 & $\begin{array}{c}\text { Weight (g) } \\
\text { in Summer }\end{array}$ & $145-361$ & $152-375$ & \\
\hline
\end{tabular}

\section{Discussion}

In our study there were significant differences in the number of fish and it has an obvious explanation that the number of shikhat fish has been increasing year after year [4] if you compare with other species of fish such as carp fish and others. Therefore, it needs accelerate solution to solve the problem such as to add a huge number of fingerlings of common carp fish with weight above $10 \mathrm{~g}$ into Mosul Dam in order to make normal balance between Carp Fish and Shikhat Fish and other local fish [4] (Christopher et al. 2006). It is a curious result that needs further investigation. As shown in previous study [7] (Christopher et al. 2006). Further study required to know the exact number of shikhat fish with their classification and other species of fish and natural food with water temperature that make new fish species to increase rapidly [3].

\section{Conclusion and Recommendation}

From the results it is an obvious that the species of a new fish that called locally (Shikhat Fish) has been increased alarmingly, the impact of climate change and natural foods (Algae, phytoplankton, zooplankton and others) have been effected in terms of increase the number of shikhat fish and decrease the number of local fish especially carp fish that have been already disappear in Mosul Dam [8-11].
In contrast, a study should include the fish specification, water biology, species of natural food such as Algae, phytoplankton and zooplankton in order to know what is the main reason is the causes of increase the shikhat fish and which kind of natural food (plankton) and water temperature have significantly impact on increasing the new fish. Overall, it can be concluded that the quality of water that contain natural food and water temperature can potentially impacting negatively on fish balancing. For this to be achieved additional research to look at the efficiency of this a new fish species, climate change and natural food on Mosul Dam is required [12-18].

\section{Future Research}

They are a number of areas that require further research and some have been outlined above. The important consideration must be to match the new species of fish, water temperature and natural food such as algae, phytoplankton, zooplankton and other. New species of fish, climate change and natural food in the combination profile of the Mosul Dam. Why do climate change and natural food such as algae, phytoplankton and zooplankton not give positive responses in all situations? Perhaps this reflects type, level and source of water, water temperature and quality of water, plankton variety to name but a few of the variables that could be investigated. Also, the international agencies should support Kurdistan Region of Iraq in terms of the impact of climate change on Tigris River, appears a new species of fish, valid research and the way of set up data. Other studies could examine the following.

\section{References}

1. Harley CD, Randall Hughes A, Hultgren KM, Miner BG, Sorte CJ, et al. (2006) The impacts of climate change in coastal marine systems. Ecol Lett 9(2): 228-41. 
2. Hoegh-Guldberg, Bruno (2010) The Impact of Climate Change on the World's Marine Ecosystems. Science 328(5985):1523-1528.

3. Oramary, Dasthal M, Sarmad Ali, Ayiad AM (2016) Feeding Common Carp Fish (Cyprinus Carpio) on natural foods (Algae, Phytoplankton, Zooplankton and others) on Tigris River in Mosul Dam at Khank Fish Hatchery in Sumel, Duhok, Kurdistan Region of Iraq. Journal of Aquaculture Research and Development 7: 413.

4. Shokri Omar Mustafa (2014) Raising and Fish production pamphlet. ( $4^{\text {th }}$ edn), Department of Aquatic, Kurdistan Region, Duhok, Iraq.

5. Wright, Andrew G (2003) Iraqi Dam Has Experts On Edge Until Inspection Eases Fears. Engineering News-Record 250(17): 14.

6. (2014) Kurdish forces retake Mosul dam from IS militants. BBC News, UK.

7. Costa-Pierce BA, Henry L, Grace Doherty (2002) Ecological Aquaculture. The evolution of blue revolution. Blackwell Science, USA, pp. 382.

8. George Chan Hong Nam (1991) A growth potential in Sarawak- Guide on Metcage fish culture.

9. Beveridge M (2004) Cage Aquaculture. ( $3^{\text {rd }}$ edn), Blackwell Publishing USA, pp. 368.

This work is licensed under Creative

DOI: 10.19080/OFOAJ.2017.02.555580
10. Shokri Omar Mustafa (2013) Raising and Fish production pamphlet. ( $3^{\text {rd }}$ edn), Department of Aquatic, Kurdistan Region, Duhok, Iraq.

11. (2004) Aquatic Animal disease significant to Australia: Identification field guide. $\left(2^{\text {nd }}\right.$ edn), Department of Agriculture, Fisheries and Forestry, Australia.

12. (2001) Fisheris Western Australia-Guidelines for seafood retailers. Australia.

13. Beveridge MCM (1984) Cage and pen fish farming: carrying capacity models and environmental impact. FAO Fish Tech Pap 255: 131.

14. Boyd CE (1982) Water quality management for pond fish culture. Developments in Aquaculture and Fisheries Science, Elsevier, Amsterdam, Netherlands, p. 318.

15. Cabrita E, Robles V, Herraez P (2008) Methods in reproductive aquaculture. Marine and freshwater species. CRC Press, Taylor \& Francis Group, UK, p. 549.

16. Wedster CD, Lim C (2002) Nutrient requirements and feeding of finfish for aquaculture. p. 418.

17. Mustafa SO (2008) Fish Raising and Production. ( $\left.2^{\text {nd }} e d n\right)$, Pamphlet, Agronomist Syndicate-Duhok- Kurdistan Region, Iraq.

18. Shokri Omar Mustafa, Personal Experiences from 1994-2017.

\section{Your next submission with Juniper Publishers} will reach you the below assets

- Quality Editorial service

- Swift Peer Review

- Reprints availability

- E-prints Service

- Manuscript Podcast for convenient understanding

- Global attainment for your research

- Manuscript accessibility in different formats

( Pdf, E-pub, Full Text, Audio)

- Unceasing customer service

Track the below URL for one-step submission https://juniperpublishers.com/online-submission.php 